\title{
Wet purpura: a sinister sign in thrombocytopenia
}

\author{
Kundan Mishra, ${ }^{1}$ Aditya Jandial, ${ }^{1}$ Pankaj Malhotra, ${ }^{1}$ Neelam Varma ${ }^{2}$
}

'Department of Internal Medicine, PGIMER, Chandigarh, India

${ }^{2}$ Department of Haematology, PGIMER, Chandigarh, India

\section{Correspondence to}

Dr Kundan Mishra, mishrak20@rediffmail.com

Accepted 24 August 2017

\section{(a) CrossMark}

To cite: Mishra K, Jandial $A$, Malhotra P, et al. BMJ Case Rep Published Online First: [please include Day Month Year]. doi:10.1136/bcr-2017222008

\section{DESCRIPTION}

A previously healthy, 38-year-old man presented with non-pruritic rash over his legs and trunk noticed 2 hours back. Examination revealed non-palpable purpura over the limbs and trunk. There was multiple 'wet purpura' over the buccal mucosa, palate and tongue (figure 1A). He had mild pallor and direct ophthalmoscopy showed bilateral fundal haemorrhage with sparing of macula. There was no organomegaly or palpable lymphadenopathy. His investigation showed haemoglobin $125 \mathrm{~g} / \mathrm{L}$, white blood cell $8.7 \times 10^{9} / \mathrm{L}$, platelet $7 \times 10^{9} / \mathrm{L}$ and normal peripheral smear. He was treated with intravenous methylprednisolone (1 $\mathrm{g}$ once a day $\mathrm{x} 3$ days) and received one single donor platelet (SDP) transfusion. His bone marrow aspirates showed increased megakaryocytes and no atypical cells or excess of blast; overall picture was consistent with immune thrombocytopenia (ITP). His platelet count on day +3 was $55 \times 10^{9} / \mathrm{L}$. He was put on oral prednisolone $(1 \mathrm{mg} / \mathrm{kg} /$ day $)$. On day +7 , he was asymptomatic with no evidence of any mucocutaneous bleed (figure 1B). He was off therapy from day +28 with platelet of $178 \times 10^{9} / \mathrm{L}$.

Thrombocytopenia (platelets $<150 \times 10^{9} / \mathrm{L}$ ) is usually caused by drug, infection, autoimmune

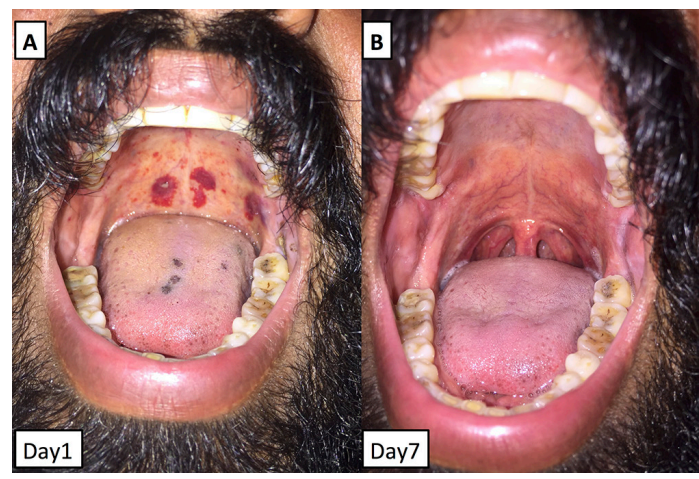

Figure 1 (A) Clinical photograph showing multiple blood-filled blisters (wet purpura) over the soft palate, tongue and buccal mucosa on day 1. (B) On day 7, complete resolution of wet purpura can be appreciated. diseases and malignancy involving bone marrow. ITP is diagnosed by excluding other causes of thrombocytopenia. ${ }^{1}$ Therapy is warranted if there is ongoing bleeding, eminent bleeding (wet purpura), severe thrombocytopenia (platelet $<30 \times 10^{9} / \mathrm{L}$ ) or a need for invasive or surgical procedure. ${ }^{2}$ First-line treatment is immunosuppression (steroid with or without immunoglobulins). Wet purpura is bloodfilled vesicles seen over the buccal mucosa, palate, tonsillar fossa or lips. ${ }^{3}$ When clinically picked, it represents eminent bleeding and demands urgent therapeutic intervention giving a gratifying result. However, if missed or ignored, a catastrophe can strike at any point of time.

\section{Learning points}

- Wet purpura is blood-filled blisters over the mucosal surface representing eminent bleeding in patients with thrombocytopenia.

- Presence of wet purpura in patients with thrombocytopenia demands aggressive therapeutic intervention.

- Early and appropriate therapy gives a gratifying result.

Contributors $\mathrm{KM}, \mathrm{AJ}, \mathrm{PM}$ and NV were involved in the management of the case. The manuscript was prepared by KM and AJ, which was vetted by all.

Competing interests None declared.

Patient consent Obtained.

Provenance and peer review Not commissioned; externally peer reviewed.

(C) BMJ Publishing Group Ltd (unless otherwise stated in the text of the article) 2017. All rights reserved. No commercial use is permitted unless otherwise expressly granted.

\section{REFERENCES}

1 George JN, Definition GJN. Definition, diagnosis and treatment of immune thrombocytopenic purpura. Haematologica 2009:94:759-62.

2 Neunert C, Lim W, Crowther M, et al. The American Society of Hematology 2011 evidence-based practice guideline for immune thrombocytopenia. Blood 2011;117:4190-207.

3 Crosby WH. Wet purpura, dry purpura. JAMA 1975;232:744-5. 
Copyright 2017 BMJ Publishing Group. All rights reserved. For permission to reuse any of this content visit http://group.bmj.com/group/rights-licensing/permissions.

BMJ Case Report Fellows may re-use this article for personal use and teaching without any further permission.

Become a Fellow of BMJ Case Reports today and you can:

- Submit as many cases as you like

- Enjoy fast sympathetic peer review and rapid publication of accepted articles

Access all the published articles

- Re-use any of the published material for personal use and teaching without further permission

For information on Institutional Fellowships contact consortiasales@bmjgroup.com

Visit casereports.bmj.com for more articles like this and to become a Fellow 